\title{
RASIO KEUANGAN DALAM MEMPREDIKSI KEBANGKRUTAN PERUSAHAAN PERTAMBANGAN BATUBARA
}

\author{
Eva Lisnawati Sidabalok ${ }^{1)}$ \\ Dwi Risma Deviyanti' \\ Yoremia Lestari Ginting ${ }^{3)}$
}

Universitas Mulawarman Samarinda ${ }^{1,2,3)}$

\begin{abstract}
The purpose of this study was to analyzed how much influence the return on assets (ROA), current ratio (CR), and debt ratio (DR) to the financial distress of coal mining companies listed in Indonesian Stock Exchange the period of 2010 - 2015. This study used secondary data obtained from IDX website with data collection method of purposive sampling then obtained 35 data sample research. Method of data analysis in this research is multiple linear regression analysis.

Result of this research is return on assets (ROA) have significant positive effect to financial distress, current ratio (CR) has no positive significant effect on financial distress, and debt ratio (DR) has a significant negative effect on financial distress of coal mining company. The results of this study obtained $R$ square value of 0.869 which means the company's financial distress condition can be predicted by using the four independent variabels.

Keywords: financial distress, return on assets, current ratio, and debt ratio.
\end{abstract}

\section{PENDAHULUAN}

\subsection{Latar Belakang Penelitian}

Akibat dari fluktuasi harga batubara di pasar Internasional yang semakin menurun, beberapa perusahaan pertambangan batubara di Indonesia mengurangi tingkat produksinya. Bahkan tidak hanya produksi batubara saja yang dikurangi tetapi pengurangan karyawan atau PHK juga terjadi di beberapa perusahaan pertambangan batubara di Indonesia. Produksi batubara yang semakin menurun dapat berdampak pada kondisi keuangan perusahaan. Apabila perusahaan tidak mampu bertahan dalam krisis global seperti ini, maka perusahaan akan mengalami kerugian yang dapat berujung pada masalah atau kesulitan keuangan (financial distress). Menurut Platt dan Platt dalam Fahmi (2012:93) mendefinisikan financial distress sebagai tahap penurunan kondisi keuangan yang terjadi sebelum terjadinya kebangkrutan atau likuidasi dimulai dari ketidakmampuan perusahaan dalam memenuhi kewajiban-kewajibannya, terutama kewajiban yang bersifat jangka pendek termasuk kewajiban likuiditas, dan juga termasuk kewajiban dalam kategori solvabilitas serta ditandai dengan laba operasi perusahaan negatif selama dua tahun berturut-turut.

Dalam penelitian ini ada beberapa rasio yang digunakan untuk memprediksi financial distress. Yang pertama adalah rasio profitabilitas (Return On Assets) yaitu salah satu dari bentuk rasio profitabilitas untuk mengukur kemampuan perusahaan dalam menghasilkan laba yang dihitung dengan membagi laba bersih dengan total aset (Kasmir,2014:196). Kedua adalah rasio likuiditas yang diukur dengan current ratio yaitu rasio untuk mengukur kemampuan perusahaan dalam membayar kewajiban jangka pendek atau utang yang segera jatuh tempo dan dihitung dengan cara membandingkan antara total aktiva lancar dengan total utang lancar (Kasmir, 
2014:134). Ketiga, rasio leverage atau rasio solvabilitas yang diukur dengan debt ratio yang dicari dengan cara membagi total hutang dengan total aset (Kasmir, 2014:151).

Financial distress dapat terjadi pada seluruh jenis perusahaan meskipun itu perusahaan besar sekalipun. Demikian pula dengan perusahaan pertambangan batubara yang tidak luput dari kondisi financial distress. Melihat kondisi perusahaan pertambangan batubara di Indonesia yang belum stabil hingga saat ini, maka penting untuk dilakukan penelitian pengaruh rasio keuangan dalam memprediksi kebangkrutan (financial distress) pada perusahaan pertambangan batubara yang terdaftar di Bursa Efek Indonesia (BEI) periode Tahun 2010-2015.

\subsection{Perumusan Masalah}

Berdasarkan latar belakang diatas, maka permasalahan dalam penelitian ini dapat dirumuskan sebagai berikut:

1. Apakah return on assets berpengaruh terhadap financial distress pada perusahaan pertambangan batubara yang terdaftar di Bursa Efek Indonesia periode 2010-2015?

2. Apakah current ratio berpengaruh terhadap financial distress pada perusahaan pertambangan batubara yang terdaftar di Bursa Efek Indonesia periode 20102015 ?

3. Apakah debt ratio berpengaruh terhadap financial distress pada perusahaan pertambangan batubara yang terdaftar di Bursa Efek Indonesia periode 2010$2015 ?$

\section{TINJAUAN PUSTAKA DAN PENGEMBANGAN HIPOTESIS}

\subsection{Signalling Theory}

Signalling theory (teori sinyal) menekankan pentingnya informasi yang dikeluarkan oleh perusahaan terhadap keputusan investasi pihak di luar perusahaan. Berdasarkan teori sinyal, jika manager mengharapkan pertumbuhan perusahaan di masa depan pada tingkat yang tinggi, mereka akan mencoba memberikan sinyal kepada investor melalui laporan keuangan (Marlinah,2014).

\subsection{Laporan Keuangan}

Menurut Fahmi (2012) laporan keuangan merupakan suatu informasi yang menggambarkan kondisi suatu perusahaan, dimana selanjutnya itu akan menjadi suatu informasi yang menggambarkan tentang kinerja suatu perusahaan. Tujuan laporan keuangan menurut PSAK No. 1 adalah memberikan informasi mengenai posisi keuangan, kinerja keuangan, dan arus kas entitas yang bermanfaat bagi sebagian besar kalangan pengguna laporan dalam pembuatan keputusan.

\subsection{Analisis Rasio Keuangan}

Menurut Kasmir $(2014 ; 104)$ analisis rasio merupakan indeks yang menghubungkan dua angka akuntansi dan diperoleh dengan membagi satu angka dengan angka lainnya, sedangkan rasio keuangan digunakan untuk mengevaluasi kondisi keuangan dan kinerja perusahaan, sehingga dari hasil rasio ini akan terlihat kondisi kesehatan perusahaan yang bersangkutan.

\subsection{Financial Distress}

Financial distress merupakan kondisi dimana keuangan perusahaan dalam keadaan tidak sehat atau krisis yang akan berujung pada kebangkrutan jika tidak segera diatasi. Fahmi (2012:93) mendefinisikan financial distress sebagai tahap penurunan kondisi keuangan sebelum terjadinya kebangkrutan yang dimulai dari 
ketidakmampuan perusahaan dalam memenuhi kewajiban-kewajibannya, terutama kewajiban yang bersifat jangka pendek termasuk kewajiban likuiditas, dan juga termasuk kewajiban dalam kategori solvabilitas.

\subsection{Mengukur Financial Distress Dengan Menggunakan Model Altman Z-Score}

Edward I Altman di New York University adalah salah satu peneliti awal yang mengkaji pemanfaatan analisis rasio keuangan sebagai alat untuk memprediksi kebangkrutan perusahaan dan menghasilkan rumus yang disebut Z-Score, rumus ini adalah model rasio yang menggunakan multiple discriminate analysis (MDA) yang memerlukan lebih dari satu rasio keuangan yang berkaitan dengan kebangkrutan

perusahaan untuk membentuk suatu model yang komprehensif (Rudianto,2013:254).

\subsection{Pengembangan Hipotesis}

\section{Pengaruh Return on Assets terhadap Financial Distress}

Return On Assets (ROA) merupakan rasio yang mengukur kemampuan perusahaan dalam menghasilkan laba bersih dengan semua aktiva yang dimiliki oleh perusahaan (Kasmir,2014:196). Dengan meningkatnya rasio profitabilitas perusahaan berarti perusahaan tersebut memiliki laba yang besar pula, sehingga kondisi perusahaan yang demikian mampu terhindar dari kondisi financial distress. $\mathrm{H}_{1}$ : Return on Assets berpengaruh terhadap financial distress.

\section{Pengaruh Current Ratio terhadap Financial Distress}

Rasio likuiditas merupakan rasio yang digunakan untuk mengukur seberapa likuidnya suatu perusahaan, yang berguna untuk mengetahui kemampuan perusahaan dalam membiayai dan memenuhi kewajiban/utang pada saat ditagih atau jatuh tempo (Kasmir,2014:145). Dengan semakin kecilnya nilai dari current ratio maka menunjukkan keadaan perusahaan masih mampu untuk membiayai kewajiban jangka pendeknya dan perusahaan dapat terhindar dari financial distress. $\mathrm{H}_{2}$ : Current Ratio berpengaruh terhadap Financial Distress.

\section{Pengaruh Debt Ratio terhadap Financial Distress}

Rasio leverage adalah rasio yang mengukur seberapa besar perusahaan dibiayai oleh utang. Rasio leverage dalam penelitian ini adalah debt ratio, dimana rasio ini diperoleh dari perbandingan total utang dibagi dengan total aset. Dengan semakin meningkatnya nilai dari debt ratio maka menandakan perusahaan dalam keadaan financial distress dikarenakan kewajibannya perusahaan yang terlalu tinggi.

$\mathrm{H}_{3}$ : Debt ratio berpengaruh terhadap financial distress.

\section{METODE PENELITIAN}

\subsection{Populasi dan Sampel}

Populasi dalam penelitian ini adalah seluruh perusahaan pertambangan batubara yang terdaftar di Bursa Efek Indonesia (BEI) periode 2010 - 2015. Data yang digunakkan adalah data panel yang merupakan gabungan dari data cross section dan time series (Ridha, dkk,2016). Pemilihan sampel penelitian dilakukan dengan menggunakan metode purposive sampling yang bertujuan untuk memperoleh sampel yang representatif sesuai dengan kriteria yang ditentukan. Adapun kriteria sampel dalam penelitian ini adalah sebagai berikut:

1. Perusahaan pertambangan batubara yang terdaftar di Bursa Efek Indonesia selama periode 2010-2015 secara terus menerus.

2. Perusahaan pertambangan batubara menyampaikan laporan keuangan 31 Desember secara rutin selama 6 tahun sesuai dengan periode penelitian yang 
diperlukan (laporan keuangan per 31 Desember merupakan laporan keuangan yang telah diaudit).

3. Perusahaan pertambangan batubara yang tidak berubah sektor selama periode 2010-2015.

4. Perusahaan pertambangan batubara yang mengalami financial distress selama periode 2010-2015.

Diperoleh sebanyak 35 data yang memenuhi kriteria sampel tersebut selama tahun 2010 sampai dengan 2015.

3.2. Variabel Independen

Return on Assets (ROA) dihitung dengan rumus sebagai berikut (Kasmir,2014:110):

$$
\text { ROA }=\frac{\text { Net Income }}{\text { Total Assets }}
$$

Current Ratio (CR) dihitung dengan rumus sebagai berikut (Kasmir,2014:135):

$$
C R=\frac{\text { Current Assets }}{\text { Current Liabilities }}
$$

Debt Ratio (DR) dihitung dengan rumus sebagai berikut (Kasmir,2014:156):

\subsection{Variabel Dependen}

$$
D R=\frac{\text { Total Liabilities }}{\text { Total Assets }}
$$

Financial distress diukur dengan menggunakan metode Altman Z-score khusus untuk perusahaan go public dengan rumus sebagai berikut (Rudianto,2013:254):

$$
Z \text {-score }=1,2 \mathrm{X}_{1}+1,4 \mathrm{X}_{2}+3,3 \mathrm{X}_{3}+0,6 \mathrm{X}_{4}+0,99 \mathrm{X}_{5}
$$

Keterangan:

$\mathrm{X}_{1}=$ Modal Kerja/Total Aset

$\mathrm{X}_{2}=$ Laba Ditahan/Total Aset

$\mathrm{X}_{3}=\mathrm{EBIT} /$ Total Aset

$\mathrm{X}_{4}=$ Nilai Pasar Modal Saham (MVE)/Nilai Buku Hutang (BVD)

$\mathrm{X}_{5}=$ Total Penjualan/Total Aset

Dasar klasifikasi dalam metode altman ini adalah sebagai berikut:
1. $Z>2,99$ = Zona "Aman"
2. $1,81<Z<2,99=$ Zona "Rawan"

3. $\mathrm{Z}<1,81=$ Zona "Distress"

\subsection{Alat Analisis}

\subsubsection{Statistik Deskriptif}

Statistik Deskriptif adalah bagian dari statistik yang berkaitan dengan pengumpulan suatu data yang bertujuan untuk mendeskripsikan data lalu disajikan baik secara numeric (distribusi frekuensi, nilai sentral, penyimpangan data, ukuran penempatan dan distribusi data) maupun grafis (grafik, table atau diagram) agar lebih mudah dibaca dan disimpulkan, namun penarikan kesimpulan hanya terbatas pada data yang diolah (Yudaruddin,2014:37). 


\subsubsection{Uji Asumsi Klasik}

\subsubsection{Uji Normalitas}

Uji normalitas digunakan untuk mengetahui apakah model regresi memiliki variabel residual (error) yang berdistribusi normal. Hal ini karena dalam uji t untuk melihat tingkat signifikasi variabel independen terhadap variabel dependen tidak dapat diaplikasikan jika residual tidak mempunyai distribusi normal (Yudaruddin,2014:129).

\subsubsection{Uji Multikolinearitas}

Uji multikolinieritas bertujuan untuk menguji apakah model regresi ditemukan adanya korelasi antar variabel bebas (independen). Model regresi yang baik seharusnya tidak terjadi korelasi di antara variabel independen. Multikolinearitas dapat dilihat dari nilai tolerance dan variance inflation factor (VIF). Jika nilai tolerance $\leq 0,10$ dan nilai VIF $\geq 10$ maka terjadi gejala multikolinearitas, sebaliknya jika nilai tolerance $\geq 0,10$ dan nilai VIF $\leq 10$ maka tidak terjadi multikolinearitas (Ghozali,2016:103-104).

\subsubsection{Uji Autokorelasi}

Uji autokorelasi bertujuan menguji apakah dalam model regresi linear ada korelasi antara kesalahan pengganggu pada periode $\mathrm{t}$ dengan kesalahan pengganggu pada periode t-1 (sebelumnya), jika terjadi korelasi maka dinamakan ada problem autokorelasi. Model regresi yang baik adalah regresi yang bebas dari autokorelasi (Ghozali,2016:107). Jika terjadi autokorelasi maka dilakukan transformasi data dan penambahan data, salah satu uji untuk mendeteksi ada tidaknya autokorelasi dapat menggunakan Durbin Watson . jika $\mathrm{DW}<\mathrm{d}_{\mathrm{L}}$ maka ada autokorelasi positif atau DW $>4-\mathrm{d}_{\mathrm{L}}$ maka ada autokorelasi negatif, sedangkan bila $\mathrm{d}_{\mathrm{u}}<\mathrm{DW}<4-\mathrm{d}_{\mathrm{u}}$ tidak terjadi autokorelasi (Yudaruddin,2014:138).

\subsubsection{Uji Heteroskedastisitas}

Uji heteroskedastisitas bertujuan untuk menguji apakah dalam model regresi terjadi ketidaksamaan variance dari residual satu pengamatan ke pengamatan yang lain. Jika variance dari satu pengamatan ke pengamatan yang lain tetap, maka disebut homoskedastisitas dan jika berbeda disebut heteroskedastisitas (Yudaruddin,2014:142). Model regresi yang baik adalah yang homoskedastisitas atau tidak terjadi heteroskedastisitas. Kebanyakan data crossection mengandung situasi heteroskedastisitas karena data ini menghimpun data yang mewakili berbagai ukuran (kecil, sedang dan besar) (Ghozali,2016:134).

\subsubsection{Uji Koefisien Determinasi $\left(\mathbf{R}^{2}\right)$}

Koefisien determinasi $\left(\mathrm{R}^{2}\right)$ pada intinya mengukur seberapa jauh kemampuan model dalam menerangkan variasi variabel dependen. Nilai koefisien determinasi adalah antara nol dan satu. Nilai $\mathrm{R}^{2}$ yang kecil berarti kemampuan variabelvariabel independen dalam menjelaskan variasi variabel dependen amat terbatas. Secara umum koefisien determinasi untuk data silang (crossection) relatif rendah karena adanya variasi yang besar antara masing-masing pengamatan, sedangkan untuk data runtun waktu (time series) biasanya mempunyai nilai koefisien determinasi yang tinggi (Ghozali,2016:95).

\subsubsection{Uji Kelayakan Model (Uji F)}

Uji kelayakan model (Uji F) digunakan untuk melihat ketelitian/kelayakan model yang dapat diketahui dari p-value (nilai peluang) hasil uji $\mathrm{F}$ hitung atau nilai 
signifikansi $F$ pada ANOVA (menguji koefisien regresi keseluruhan) (Yudaruddin,2014:121).

\subsubsection{Uji Koefisien Regresi Secara Parsial (Uji t)}

Uji statistik t pada dasarnya menunjukkan seberapa jauh pengaruh satu variabel penjelas/independen secara individual dalam menerangkan variasi variabel dependen (Ghozali,2016:97). Uji t digunakan untuk menguji koefisien regresi secara parsial dari variabel independennya.

\subsubsection{Analisis Regresi Linear Berganda}

Analisis regresi linear berganda dengan menggunakan metode kuadran terkecil akan menghasilkan suatu model/persamaan yang akan digunakan untuk melihat hubungan antara variabel independen terhadap dependen. Analisis regresi linier berganda untuk menjawab permasalahan penelitian, yaitu pengaruh return on assets, current ratio, dan debt ratio terhadap financial distress perusahaan. Persamaan analisis regresi linier berganda adalah sebagai berikut:

$$
\mathbf{Y}=\mathbf{a}+\mathbf{b}_{1} \mathbf{X}_{1}+\mathbf{b}_{2} \mathbf{X}_{2}+\mathbf{b}_{3} \mathbf{X}_{3}+\mathbf{e}
$$

Keterangan:

\begin{tabular}{|c|c|}
\hline $\mathrm{Y}$ & $=$ financial distress \\
\hline $\mathrm{a}$ & $=$ konstanta \\
\hline $\mathrm{b}_{1}, \mathrm{~b}_{2}, \mathrm{~b}_{3}, \mathrm{~b}_{4}$ & $=$ koefisien regresi \\
\hline $\mathrm{X}_{1}$ & $=$ return on assets \\
\hline $\mathrm{X}_{2}$ & $=$ current ratio \\
\hline $\mathrm{X}_{3}$ & $=$ debt ratio \\
\hline & $=$ standar error \\
\hline
\end{tabular}

IV. HASIL DAN PEMBAHASAN

4.1. Hasil Statistik Deskriptif

Tabel 4.1 Hasil Statistik Deskriptif

\begin{tabular}{lrrrrr}
\hline \multicolumn{7}{c}{ Descriptive Statistics } \\
\hline & N & \multicolumn{1}{c}{ Min } & \multicolumn{1}{c}{ Max } & Mean & Std. Deviation \\
\hline ROA & 35 &,- 64 &, 04 &,- 0666 &, 13106 \\
CR & 35 &, 10 & 3,26 & 1,5249 &, 69047 \\
DR & 35 &, 27 & 1,86 &, 6949 &, 30220 \\
FD & 35 & $-5,09$ & 1,71 &, 6703 & 1,25222 \\
Valid N (listwise) & 35 & & & & \\
\hline \multicolumn{5}{l}{ Sumber: Data sekunder yang diolah (SPSS 22) }
\end{tabular}

4.2. Hasil Uji Asumsi Klasik

4.2.1. Hasil Uji Normalitas

Tabel 4.2 Hasil Uji Normalitas

One-Sample Kolmogorov-Smirnov Test

\begin{tabular}{llr}
\hline & & Unstandardized Residual \\
\hline $\mathrm{N}$ & & 35 \\
Normal & Mean &, 0000000 \\
Parameters ${ }^{\mathrm{a}, \mathrm{b}}$ & Std. Deviation &, 45262106 \\
Most Extreme & Absolute &, 121 \\
Differences & Positive &, 121 \\
& Negative &,- 079 \\
Test Statistic & &, 121
\end{tabular}


Asymp. Sig. (2-tailed) $200^{\mathrm{c}, \mathrm{d}}$

a. Test distribution is Normal.

b. Calculated from data.

c. Lilliefors Significance Correction.

d. This is a lower bound of the true significance.

Sumber: Data sekunder yang diolah (SPSS 22)

Dari tabel diatas dapat disimpulkan bahwa data residual dalam model regresi telah terdistribusi secara normal karena nilai Asymp. Sig. (2-tailed) sebesar 0,200 > signifikansi 0,05 .

\subsubsection{Hasil Uji Multikolinearitas}

Tabel 4.3 Hasil Uji Multikolinearitas

\begin{tabular}{|c|c|c|c|}
\hline \multicolumn{4}{|c|}{ Coefficients $^{\mathrm{a}}$} \\
\hline & & \multicolumn{2}{|c|}{ Collinearity Statistics } \\
\hline \multicolumn{2}{|c|}{ Model } & Tolerance & VIF \\
\hline \multirow[t]{3}{*}{1} & ROA &, 699 & 1,431 \\
\hline & $\mathrm{CR}$ &, 744 & 1,344 \\
\hline & DR & .716 & 1,397 \\
\hline
\end{tabular}

Sumber: Data sekunder yang diolah (SPSS 22)

Dari tabel diatas menunjukkan bahwa besarnya nilai VIF masing-masing variabel bebas lebih kecil dari 10. Hasil pengujian model regresi tersebut menunjukkan tidak adanya gejala multikolinearitas dalam model regresi. Hal ini berarti bahwa semua variabel bebas layak digunakan sebagai prediktor.

\subsubsection{Hasil Uji Autokorelasi}

\begin{tabular}{lr}
\multicolumn{2}{c}{ Tabel 4.4 Hasil Runs Test } \\
Runs Test
\end{tabular}

a. Median

Sumber: Data sekunder yang diolah (SPSS 22)

Berdasarkan hasil pada tabel diatas dapat dilihat bahwa nilai test adalah $-0,05793$ dengan probabilitas 0,171 dan tidak signifikan pada 0,05 yang berarti hipotesis 
nol diterima, sehingga dapat disimpulkan bahwa residual random atau tidak terjadi autokorelasi antar nilai residual.

\subsubsection{Hasil Uji Heteroskedastisitas}

Tabel 4.5 Hasil Uji Heterokedastisitas

Coefficients $^{\mathrm{a}}$

\begin{tabular}{|c|c|c|c|c|c|}
\hline \multirow[b]{2}{*}{ Model } & \multicolumn{2}{|c|}{$\begin{array}{l}\text { Unstandardized } \\
\text { Coefficients }\end{array}$} & $\begin{array}{c}\text { Standardized } \\
\text { Coefficients }\end{array}$ & \multirow[b]{2}{*}{$\mathrm{t}$} & \multirow[b]{2}{*}{ Sig. } \\
\hline & B & Std. Error & Beta & & \\
\hline 1 (Constant) & ,282 & ,233 & & 1,210 &, 235 \\
\hline ROA & ,232 & ,488 & ,098 & ,476 & 638 \\
\hline CR &,- 072 & ,090 &,- 160 &,- 802 & ,428 \\
\hline DR & ,239 & ,210 & ,231 & 1,138 & ,264 \\
\hline
\end{tabular}

a. Dependent Variable: Absolute

Sumber: Data sekunder yang diolah (SPSS 22)

Berdasarkan hasil pada tabel diatas menunjukkan bahwa seluruh variabel bebas memiliki nilai signifikansi $>0,05$ yaitu 0,638 (ROA), 0,428 (CR), dan 0,264 (DR) sehingga data tidak memiliki gejala heteroskedastisitas.

\subsection{Hasil Koefisien Determinasi $\left(R^{2}\right)$}

Tabel 4.6 Hasil Koefisien Determinasi Model Summary ${ }^{\text {b }}$

\begin{tabular}{lrrrr}
\hline \multicolumn{5}{c}{ Model Summary } \\
Model & R & R Square & $\begin{array}{c}\text { Adjusted R } \\
\text { Square }\end{array}$ & $\begin{array}{c}\text { Std. Error of the } \\
\text { Estimate }\end{array}$ \\
\hline 1 &, $932^{\text {a }}$ &, 869 &, 857 &, 47402 \\
\hline
\end{tabular}

a. Predictors: (Constant), DR, CR, ROA

b. Dependent Variable: FD

Sumber: Data sekunder yang diolah (SPSS 22)

Tabel diatas menunjukkan bahwa nilai $\mathrm{R}$ sebesar 0,932 yang berarti tingkat keeratan hubungan antara variabel dependen dengan variabel independen adalah tinggi. Nilai $\mathrm{R}$ Square $\left(\mathrm{R}^{2}\right)$ sebesar 0,869 menunjukkan bahwa $86,9 \%$ variasi variabel dependen dapat dijelaskan oleh variabel independen, sedangkan sisanya $13,1 \%$ dijelaskan oleh variabel independen lain yang tidak termasuk dalam model penelitian ini. Standar error of the estimate sebesar 0,47402 $<1,25222$ (standar deviasi financial distress) berarti model regresi semakin tepat dalam memprediksi variabel dependen. 


\subsection{Hasil Uji Kelayakan Model (Uji F)}

Tabel 4.7 Hasil Uji Kelayakan Model (Uji F)

\begin{tabular}{|c|c|c|c|c|c|c|}
\hline \multicolumn{7}{|c|}{ ANOVA $^{a}$} \\
\hline Model & & $\begin{array}{l}\text { Sum of } \\
\text { Squares }\end{array}$ & $\mathrm{df}$ & $\begin{array}{l}\text { Mean } \\
\text { Square }\end{array}$ & $\mathrm{F}$ & Sig. \\
\hline \multirow[t]{3}{*}{1} & Regression & 46,316 & 3 & 15,439 & 68,711 &, $000^{\mathrm{b}}$ \\
\hline & Residual & 6,965 & 31 & ,225 & & \\
\hline & Total & 53,282 & 34 & & & \\
\hline
\end{tabular}

a. Dependent Variable: FD

b. Predictors: (Constant), DR, CR, ROA

Sumber: Data sekunder yang diolah (SPSS 22)

Dari tabel diatas menunjukkan bahwa nilai $\mathrm{F}$ hitung sebesar 68,711 dan hasil ini lebih besar daripada $\mathrm{F}$ tabel yaitu sebesar 2,87 dengan signifikansi 0,000. Karena signifikansi lebih kecil dari 0,05 maka dapat disimpulkan bahwa model regresi dapat digunakan untuk memprediksi financial distress atau dapat dikatakan bahwa model regresi adalah model yang baik/layak (goodness of fit).

\subsection{Hasil Uji Parsial (Uji t)}

\section{Tabel 4.8 Hasil Uji Parsial (Uji t)}

Coefficients $^{\mathrm{a}}$

\begin{tabular}{|c|c|c|c|c|c|}
\hline \multirow[b]{2}{*}{ Model } & \multicolumn{2}{|c|}{ Unstandardized Coefficients } & \multicolumn{3}{|l|}{ Standardized } \\
\hline & $\mathrm{B}$ & Std. Error & Beta & $\mathrm{t}$ & Sig. \\
\hline 1 (Constant) & 1,461 &, 352 & & 4,149 &, 000 \\
\hline $\mathrm{ROA}$ & 7,210 & ,737 & ,760 & 9,788 & 000 \\
\hline $\mathrm{CR}$ & , 188 & ,136 & 104 & 1,381 & , 177 \\
\hline DR &,- 852 & ,318 &,- 206 & $-2,681$ & 012 \\
\hline
\end{tabular}

a. Dependent Variable: FD

Sumber: Data sekunder yang diolah (SPSS 22)

Dari tabel di atas menunjukkan bahwa variabel ROA berpengaruh signifikan terhadap FD, hal ini dapat dilihat dari signifikansi ROA sebesar 0,000 yang lebih kecil dari 0,05. Variabel CR tidak berpengaruh signifikan terhadap FD, hal ini dapat dilihat dari tingkat signifikansi sebesar 0,177 yang lebih besar dari 0,05. Variabel DR berpengaruh signifikan terhadap FD, hal ini dapat dilihat dari tingkat signifikansi 0,012 lebih kecil dari 0,05.

\subsection{Hasil Regresi Linear Berganda}

Tabel coefficients di atas menunjukkan data hasil regresi linear berganda, dan diperoleh persamaan regresi sebagai berikut:

$$
\mathrm{Y}=1,461+7,210 \mathrm{ROA}+\mathbf{0 , 1 8 8 C R}-\mathbf{0 , 8 5 0 D R}+\mathrm{e}
$$


Dari model persamaan tersebut, maka diperoleh penjelasan hasil sebagai berikut:

1. Konstanta

Konstanta sebesar 1,461 menyatakan bahwa jika variabel return on assets $\left(\mathrm{X}_{1}\right)$, current ratio $\left(\mathrm{X}_{2}\right)$, dan debt ratio $\left(\mathrm{X}_{3}\right)$ diperhitungkan, maka nilai financial distress (Y) perusahaan akan meningkat sebesar 1,461 persen.

2. Pengaruh Return on Assets $\left(\mathrm{X}_{1}\right)$ terhadap financial distress $(\mathrm{Y})$

Hasil pengujian menunjukkan nilai variabel return on assets $\left(\mathrm{X}_{1}\right)$ sebesar 7,210 dengan tingkat signifikansi $0,000<0,05$ berarti bahwa model tersebut signifikan. Nilai variabel return on assets (ROA) sebesar 7,210 berarti bahwa bila terjadi kenaikan return on assets sebesar 1\% maka nilai financial distress (z-score) akan mengalami peningkatan sebesar 7,210 dengan asumsi bahwa variabel independen yang lain konstan.

3. Pengaruh current ratio $\left(\mathrm{X}_{2}\right)$ terhadap financial distress $(\mathrm{Y})$

Hasil pengujian menunjukkan nilai variabel current ratio $\left(\mathrm{X}_{2}\right)$ sebesar 0,188 dengan tingkat signifikansi 0,177 $>0,05$ berarti bahwa model tersebut tidak signifikan. Nilai variabel current ratio (CR) sebesar 0,188 berarti bahwa setiap kenaikan current ratio sebesar $1 \%$ maka nilai financial distress (zscore) akan mengalami peningkatan sebesar 0,188 dengan asumsi bahwa variabel independen yang lain konstan.

4. Pengaruh debt ratio $\left(\mathrm{X}_{3}\right)$ terhadap financial distress $(\mathrm{Y})$

Hasil pengujian menunjukkan nilai variabel debt ratio $\left(\mathrm{X}_{3}\right)$ sebesar $-0,852$ dengan tingkat signifikansi $0,012<0,05$ berarti bahwa model tersebut signifikan. Nilai variabel debt ratio (DR) sebesar $-0,852$ berarti bahwa setiap kenaikan debt ratio $1 \%$ maka nilai financial distress (z-score) akan mengalami penurunan sebesar 0,852 dengan asumsi bahwa variabel independen yang lain konstan.

\subsection{Pembahasan}

$\mathrm{H}_{1}$ : Return on assets berpengaruh terhadap financial distress

Hasil pengujian untuk variabel ROA terhadap financial distress memberikan hasil t hitung sebesar 9,788 dengan signifikansi sebesar $0,000<0,05$. Dengan demikian menunjukkan bahwa ROA mempunyai pengaruh signifikan terhadap kondisi financial distress, hal ini berarti hipotesis satu (H1) diterima. Hasil penelitian ini sejalan dengan penelitian yang dilakukan oleh Muhtar dan Aswan (2017) yang menyatakkan bahwa ROA berpengaruh signifikan terhadap kondisi financial distress perusahaan. Berdasarkan konsep, semakin tinggi ROA 
perusahaan maka semakin kecil kemungkinan perusahaan akan mengalami financial distress dan sebaliknya, apabila profitabilitas (ROA) perusahaan menurun maka akan menyebabkan perusahaan mengalami financial distress.

\section{$\mathrm{H}_{2}$ : Current ratio berpengaruh terhadap financial distress}

Hasil pengujian untuk variabel CR terhadap kondisi financial distress memberikan hasil $t$ hitung sebesar 1,381 dengan signifikansi sebesar 0,177 > 0,05. Dengan demikian menunjukkan bahwa CR tidak berpengaruh signifikan terhadap kondisi financial distress perusahaan, hal ini berarti hipotesis dua (H2) ditolak. Hasil pengujian ini tidak sejalan dengan penelitian yang dilakukan oleh Ardiyanto (2013), Atika, dkk (2013) dan Khaliq et al (2014) yang menyatakan bahwa variabel CR berpengaruh terhadap kondisi financial distress perusahaan. Dalam penelitian ini CR tidak berpengaruh signifikan terhadap kondisi financial distress karena perusahaan-perusahaan pertambangan batubara yang menjadi sampel dalam penelitian ini memiliki kemampuan yang baik dalam memenuhi kewajiban jangka pendek dengan aktiva lancar yang dimilikinya.

\section{$\mathrm{H}_{3}$ : Debt ratio berpengaruh terhadap financial distress}

Hasil pengujian untuk variabel DR terhadap financial distress memberikan hasil $\mathrm{t}$ hitung sebesar $-2,681$ dengan signifikansi sebesar $0,013<0,05$. Dengan demikian menunjukkan bahwa DR berpengaruh signifikan terhadap kondisi financial distress perusahaan, hal ini berarti hipotesis tiga (H3) diterima. Hasil penelitian ini sejalan dengan penelitian Ardiyanto (2011), Andre (2013), Martha (2013), Atika, dkk (2013), dan Khaliq et al (2014) yang menyatakan bahwa DR berpengaruh signifikan terhadap kondisi financial distress perusahaan. Berdasarkan konsep, penggunaan hutang yang terlalu tinggi dapat membahayakan perusahaan berpotensi mengalami financial distress.

\section{PENUTUP}

\subsection{Simpulan}

Berdasarkan hasil analisis yang telah dikemukakan pada bab sebelumnya, maka dapat ditarik simpulan sebagai berikut:

1. Return on assets (ROA), current ratio (CR), dan debt ratio (DR) memiliki kemampuan memprediksi kondisi financial distress sebesar 86,9\% dimana secara umum hasil tersebut menunjukkan bahwa model ini cukup bagus untuk memprediksi financial distress. 
2. Return on assets (ROA) berpengaruh signifikan terhadap prediksi kondisi financial distress pada perusahaan pertambangan batubara yang terdaftar di BEI periode tahun 2010-2015. Variabel ROA merupakan variabel yang paling dominan dalam memprediksi kondisi financial distress.

3. Current ratio (CR) tidak berpengaruh signifikan terhadap financial distress perusahaan pertambangan batubara yang terdaftar di BEI periode tahun 20102015. Sehingga current ratio (CR) tidak dapat digunakan untuk memprediksi kondisi financial distress.

4. Debt ratio (DR) berpengaruh signifikan terhadap financial distress pada perusahaan pertambangan batubara yang terdaftar di BEI periode tahun 20102015.

\subsection{Keterbatasan}

Keterbatasan dari penelitian ini yaitu sampel yang digunakan dalam penelitian ini terbatas pada perusahaan sektor pertambangan batubara saja, sehingga hasil penelitian dan variabel-variabel yang digunakan dalam penelitian belum bisa dibandingkan dengan perusahaan-perusahaan pada sektor lainnya dan periode penelitian ini juga hanya selama 6 tahun penelitian.

\section{DAFTAR PUSTAKA}

Andre, Orina. 2013. Pengaruh Profitabilitas, Likuiditas dan Leverage Dalam Memprediksi Financial Distress (Studi Empiris Pada Perusahaan Aneka Industri yang Terdaftar di BEI). Padang, Fakultas Ekonomi, Universitas Negeri Padang.

Ardiyanto, Feri Dwi dan Presetiono. 2011. Prediksi Rasio Keuangan terhadap kondisi Financial Distress Perusahaan Manufaktur yang terdaftar di BEI, Jurnal Dinamika Ekonomi dan Bisnis, Vol.8 No.1

Dinas Pertambangan dan Energi Provinsi Kalimantan Timur. 2014. IUP Kalimantan Timur.

http://pertambangan.kaltimprov.go.id/index.php?option=com content\&view= article\&id=133\%3Aiup-kalimantan-timur\&catid=40\%3Apertambanganumum\&Itemid=103\&lang=in. Diakses tanggal 12 Maret 2017.

Dwijayanti, S, Patricia Febrina. 2010. Penyebab, Dampak, dan Prediksi dari Financial Distress Serta Solusi untuk Mengatasi Financial Distress. Jurnal Akuntansi Kontemporer, Vol. 2 No. 2, Juli 2010, hal. 191-205.

Fachrudin, Khaira Amalia. 2008. Kesulitan Keuangan Perusahaan dan Personal. Medan: USU Press. 
Fahmi, Irham. 2012. Analisis Kinerja Keuangan, Cetakan Kesatu. Penerbit Alfabeta. Bandung.

2014. Analisis Laporan Keuangan, Cetakan Keempat. Penerbit Alfabeta. Bandung.

Ghozali, Imam. 2016. Aplikasi Analisis Multivariate Dengan Program IBM SPSS

23. Cetakan VIII. Badan Penerbit Universitas Diponegoro. Semarang

Hery. 2013. Teori Akuntansi Suatu Pengantar. Lembaga Penerbit Fakultas Ekonomi Universitas Indonesia. Jakarta.

Investments, Indonesia. Produksi dan Ekspor Batubara Indonesia. http://www.indonesia-investments.com/id/bisnis/komoditas/batubara/item236. Diakses 14 Maret 2017.

Irfan, Mochamad. 2014. Analisis Financial Distress Dengan Pendekatan Altman ZScore untuk Memprediksi Kebangkrutan Perusahaan Telekomunikasi. Jurnal Ilmu \& Riset Manajemen Vol. 3 No. 1 (2014)

Kasmir. 2014. Analisis Laporan Keuangan, Cetakan ke-7. Rajagrafindo Persada. Jakarta.

Khaliq, Ahmad et al. 2014. Identifying Financial Distress Firms: A Case Study of Malaysia's Government Linked Companies (GLC). International Journal of Economics, Finance and Management Vol. 3 No. 3

Lokollo, Antonius. 2013. Pengaruh Modal Kerja Dan Rasio Keuangan Terhadap Profitabilitas Pada Industri Manufaktur Yang Terdaftar Di Bursa Efek Indonesia (BEI) Tahun 2011. Skripsi. Universitas Diponegoro.

Marlinah, Aan. 2014. Pengaruh Kebijakan Modal Kerja Dan Faktor Lainnya Terhadap Profitabilitas Perusahaan Manufaktur. Jurnal Bisnis dan Akuntansi, Vol. 16, No. 2.

Martani Dwi, dkk. 2012. Akuntansi Keuangan Menengah Berbasis PSAK. Salemba Empat. Jakarta.

Mas'ud, Imam dan Srengga, Reva Maymi. 2011. Analisis Rasio Keuangan untuk Memprediksi Kondisi Financial Distress Perusahaan Manufaktur yang Terdaftar di Bursa Efek Indonesia. Jember, Fakultas Ekonomi, Unversitas Jember.

Muhtar dan Aswan. 2017. Pengaruh Kinerja Keuangan Terhadap Terjadinya Kondisi Financial Distress Pada Perusahaan Telekomunikasi di Indoneisa. Jurnal Bisnis Manajemen dan Informatika Vol 13 No. 3 Februari 2017.

Prihtiyani, Eny. 17 Juli 2012. Harga Batubara Acuan Terus Menurun. http://bisniskeuangan.kompas.com/read/2012/07/17/16273582/Harga.Batu.Ba ra.Acuan.Terus.M.enurun. Diakses 14 Maret 2017. 
Rahayu, dkk. 2016. Analisis Financial Distress Dengan Menggunakan Metode Altman Z-score, Springate, Dan Smijewski Pada Perusahaan Telekomunikasi. E-journal Bisma Universitas Pendidikan Ganesha Vol.4.

Ridha, dkk. 2016. Pengaruh Laba Bersih, Laba Operasi, Arus Kas Operasi Terhadap Aktivitas Volume Perdagangan Saham. Jurnal Magister Akuntansi. ISSN 2302-0199

Rudianto. 2013. Akuntansi Manajemen Informasi Untuk Pengambilan Keputusan Strategis. Penerbit Erlangga. Jakarta.

Vitarianjani, Novadea. 2015. Prediksi Kondisi Financial Distress dan Faktor Yang Mempengaruhi Studi Empiris Pada Perusahaan Batubara Yang Terdaftar di Bursa Efek Indonesia Tahun 2011-2014, Jember, Fakultas Ekonomi, Universitas Jember.

www.idx.co.id, diakses tanggal 05 Mei 2017.

Yudaruddin, Rizky. 2014. Statistik Ekonomi. Cetakan Pertama. Interpena. Yogyakarta. 